\title{
Changes in $T$ and $B$ lymphocyte populations in the lymph nodes draining the uterus in pregnant mice
}

\author{
Anne Newport* and Jan Carter \\ Department of Biochemistry, Trinity College, Dublin, Ireland
}

\begin{abstract}
Summary. Using indirect immunofluorescence and fluorescence microscopy, changes in the proportion of $\mathrm{T}$ and $\mathrm{B}$ lymphocytes in the para-aortic lymph nodes draining the pregnant uterus and the brachial nodes from the same animal were examined at 8,15 , 17 and 19 days of pregnancy and 2 and 6 days post partum. Syngeneic and allogeneic matings of CBA and C57BL10.ScSn mice were examined. There was a dramatic increase in the level of $B$ cells in the para-aortic nodes after 15 days. This peaked around the time of parturition and did not fall until 6 days post partum. There was no change in the level of $B$ cells in the brachial nodes. There was an indication from syngeneic and allogeneic matings of CBA mice that the percentage of $T$ cells dropped during the second half of pregnancy. It is concluded that allogenicity, seminal plasma, implantation, multiparity, the placenta and the male fetus were not responsible for the observed increase in the level of B lymphocytes.
\end{abstract}

\section{Introduction}

It can be argued that the feto-placental unit is an allograft because it possesses paternally inherited antigens. Exposure of mice to transplantation antigens of allogeneic tissue is normally followed by regional lymph node changes (Davies, Carter, Leuchars, Wallis \& Koller, 1969; Rowley, Gowans, Atkins, Ford \& Smith, 1972). Increases in size and weight (Maroni \& DeSousa, 1973; Beer, Scott \& Billingham, 1975), lymphocyte accumulation and cellular proliferation (Ansell, McDougall, Speedy \& Inchley, 1978) have been found in the lymph nodes draining the uterus during allogeneic pregnancy, although Hetherington \& Humber (1977) could find no difference in weight changes during allogeneic or syngeneic pregnancies. Expression of allogeneic antigens on the feto-placental unit is well established (Simmons \& Russell, 1966; Searle, Sellens, Elson, Jenkinson \& Billington, 1976; Carter, 1976, 1978) and this would be consistent with the view that there is a response to fetal antigens in the para-aortic lymph nodes.

The behaviour of different kinds of lymphocytes during pregnancy has not yet been defined with any precision. There is conflicting evidence of $T$ and $B$ cell changes in human blood: decreased numbers of $T$ lymphocytes and increased numbers of B lymphocytes have been reported by Strelkauskas, Wilson \& Dray, (1975), and Cornfield, Jencks, Binder \& Rath (1979), while others found no such changes (Baines, Pross \& Millar, 1977a; Hirahara et al., 1980). All these studies failed to take into consideration the possible sequestration of circulating lymphocytes in the lymph nodes draining the uterus. Inbred strains of mice can be used to measure lymphocyte populations in the nodes draining the uterus and to determine whether the allogenicity of the fetus is responsible for any of the observed changes. Functional changes in $\mathrm{T}$ cells have been observed in the draining nodes. A defect in $T$ proliferative responses (Gottesman \& Stutman, 1981) and

* Present address: Department of Haematology, Central Pathology Laboratories, St. James Hospital, Dublin, Ireland.

0022-4251/83/020433-08\$02-00/0

(C) 1983 Journals of Reproduction \& Fertility Ltd 
impairment of the development of cytotoxic T cells have been observed (Clark, McDermott \& Szewczuk, 1980). As in human studies, previous experiments have produced conflicting results for $\mathrm{T}$ and $\mathrm{B}$ cells in mice: Baines, Pross \& Millar (1977b) could find no change in T and B cell numbers in the para-aortic lymph nodes during syngeneic or allogeneic pregnancies, but ChatterjeeHasrouni, Santer \& Lala (1980) reported an initial decrease in the absolute number of $\mathrm{T}$ cells in syngeneic and allogeneic pregnancies and a late increase in $\mathbf{B}$ cells in allogeneic pregnancies.

In the present study with several mouse strains, the proportions of $\mathbf{T}$ and $\mathbf{B}$ lymphocytes in the para-aortic lymph node during pregnancy and post partum were compared with those in the brachial nodes taken from the same animal. The effects of various other substances and conditions on the percentage of B lymphocytes in the para-aortic nodes of CBA $\times$ CBA mice have also been investigated.

\section{Materials and Methods}

Animals. The inbred mouse strains CBA/Ca $\left(\mathrm{H} 2^{\mathrm{k}}\right), \mathrm{C} 57\left(\mathrm{H} 2^{\mathrm{b}}\right)$ and $\mathrm{C} 57 . \mathrm{D}_{2}\left(\mathrm{H} 2^{\mathrm{d}}\right)$ were bred and maintained under conventional conditions in the Wellcome Animal Laboratories, Trinity College, Dublin. Female mice were mated at 8-10 weeks of age with normal or vasectomized males and the day of finding a vaginal plug was called Day 1 of pregnancy.

Ovariectomy. Ovariectomy was performed under halothane anaesthesia at 3-4 weeks of age and the animals were allowed to recover for 5-6 weeks before use.

Placental pregnancy. Mice were lightly anaesthetized at 12-15 days of gestation and after palpation the amniotic sac of each fetus was burst by digital pressure (Newton, 1935).

Multiple pregnancy. For experiments on fourth pregnancies, the first 3 litters were removed within 7 days of birth and the females re-mated.

Embryo transfers. Superovulation of $14-\mathrm{g}$ females was induced by 5 i.u. PMSG (Folligon; Intervet, Cambridge, U.K.) followed $48 \mathrm{~h}$ later by 5 i.u. hCG (Chorulon; Intervet), i.e. $12 \mathrm{~h}$ before the mid-point of the subsequent period of darkness (Gates, 1971). The females were mated during this dark period and checked for plugs the following morning. Embryos were flushed from the uterus at 3.5 days of pregnancy with phosphate-buffered saline (PBS). Viable embryos were transferred in PBS plus $10 \%$ fetal calf serum (FCS; Gibco Europe, Glasgow, U.K.) to the uteri of 2.5-3.5-day pseudopregnant anaesthetized recipients (Dickmann, 1971).

Cell preparation. Para-aortic and brachial nodes were removed from pregnant animals at 8,15 , 17 and 19 days of pregnancy and at 2 and 6 days post partum. The lymph nodes were disrupted by pressing them through a stainless-steel wire mesh into Hanks Balanced Salt Solution (HBSS) supplemented with $0 \cdot 1 \%(\mathrm{w} / \mathrm{v})$ bovine serum albumin (BSA; Sigma, Poole, U.K.) and $0.2 \%(\mathrm{w} / \mathrm{v}$ ) sodium azide. The cells were washed twice with cold HBSS. All centrifugations were at $4^{\circ} \mathrm{C}$ and 300 $g$ for $5 \mathrm{~min}$. Red blood cells were eliminated by addition of $1 \mathrm{ml} 0.83 \%(\mathrm{w} / \mathrm{v})$ ammonium chloride, buffered with Tris at $\mathrm{pH} 7 \cdot 2$, for $10 \mathrm{~min}$ at room temperature. This treatment was stopped with 10 $\mathrm{ml}$ ice-cold HBSS followed by centrifugation. The cells were resuspended and $0.375 \times 10^{6}$ cells were centrifuged in a $50 \times 6 \mathrm{~mm}$ tube and the pellet used in fluorescence staining assays.

Indirect fluorescence assay for $B$ lymphocytes. The cells were incubated with $15 \mu 1$ rabbit antimouse $\mathrm{F}(\mathrm{ab})_{2}$ (Nordic Immunological Laboratories, Maidenhead, U.K.) for $30 \mathrm{~min}$ on ice. Normal rabbit serum was used as a control. After 2 washes with cold HBSS the surface immunoglobulin was visualized by incubation for $30 \mathrm{~min}$ on ice in the dark with rhodamine-labelled goat anti-rabbit IgG (Nordic). After 2 further washes the cells were mounted on a microscope slide in $5 \mu$ l glycerolglycine mountant. Number 1 coverslips were used and sealed with clear nail varnish. The cells were examined using a Zeiss Jena Laboval microscope equipped with phase-contrast incidencefluorescence optics and an Osram 200 mercury arc lamp. Two hundred cells were counted in a blind assay system and the numbers of those which showed membrane fluorescence were calculated as a percentage of the total. Controls were done for each assay and these showed no membrane fluorescence. 
Indirect fluorescence assay for T lymphocytes. T lymphocytes were identified by incubation with IgM anti-Thy-1.2 FD75 monoclonal antibody (Olac 1976, Bicester, U.K.) followed by fluoresceinlabelled rabbit anti-mouse IgM (Nordic). Normal mouse serum was used instead of the monoclonal antibody as a control. This control, which was done for each experiment, showed that at the level of sensitivity obtained in this assay there was no staining of IgM receptor-bearing B cells. The other technical details of the assay were the same as those for the B-cell assay.

Hormone treatments. Ovariectomized mice were injected subcutaneously with $0.025 \mathrm{ng}$ oestradiol-17 $\beta$ (Sigma) in $0.1 \mathrm{ml}$ sunflower oil every $48 \mathrm{~h}$ and $1 \mathrm{mg}$ progesterone (Promone-E: Upjohn Ltd, Crawley, U.K.) in $0 \cdot 1 \mathrm{ml}$ distilled water every 6 days. This schedule was continued for 15 days.

Chromosome spreads. Spreads were made according to the method of Evans, Burtenshaw \& Ford (1972). Spleens from 17-19-day fetuses were disrupted in Trowells T-8 medium (Gibco Europe) plus $20 \% \mathrm{FCS}$. The fragments were incubated for $1 \mathrm{~h}$ at $37^{\circ} \mathrm{C}$ with $0.001 \%$ colchicine (BDH Chemicals Ltd, Poole, U.K.) in $5 \% \mathrm{CO}_{2}$ in air and then transferred to $2 \mathrm{ml} 1 \%(\mathrm{w} / \mathrm{v})$ sodium citrate for 4-12 min. They were then fixed in freshly prepared ethanol : acetic acid $(3: 1 \mathrm{v} / \mathrm{v})$ for $\sim 1 \mathrm{~h}$ and subsequently blotted dry and added to 5-6 drops of $60 \%(\mathrm{v} / \mathrm{v})$ acetic acid on a microscope slide previously heated to $55-60^{\circ} \mathrm{C}$. After rapid agitation the excess fluid was discarded and the slides were stained with $5 \%(\mathrm{v} / \mathrm{v})$ toluidine blue (Gurr, London, U.K.) for 2 min. 'Male' and 'female' spreads were determined by the method of Stitch \& Hsu (1960).

Statistical analysis. Estimates of significance were made using analysis of variance, Student's $t$ test and paired $t$ tests as appropriate (Moroney, 1951). The main factors of an analysis of variance were tested against the interaction variance according to Snedecor \& Cochran (1971).

\section{Results}

$B$ lymphocyte levels in the brachial and para-aortic lymph nodes of syngeneic and allogeneic matings

The percentage of B lymphocytes in the para-aortic lymph nodes of CBA $\times$ CBA, CBA $\times$ C57, $\mathrm{C} 57 \times \mathrm{CBA}$ and $\mathrm{C} 57 \times \mathrm{C} 57 . \mathrm{D}_{2}$ matings increased during pregnancy; there was no change in the brachial nodes taken from the same animals. The normal percentage of $B$ lymphocytes in the paraaortic lymph nodes of CBA mice was $7 \cdot 1 \pm 0.8 \%$; the rise during pregnancy was not obvious until 15 days, peaked at 19 days and had returned to normal 6 days after parturition (Text-fig. 1). In nonpregnant C57 females, the percentage of B lymphocytes in the para-aortic lymph node was $20.0 \pm$ $1 \cdot 6$, which compares with $24.6 \pm 1.8 \%$ at 19 days of gestation for the syngeneic mating and $33.5 \pm$ $1.2 \%$ for the allogeneic mating (Text-fig. 2). An analysis of variance performed between the percentage of B cells in the para-aortic lymph nodes of CBA and C57 allogeneic and syngeneic matings showed that there was a significant interaction between the influence of time $(t)$ during gestation and strain combination $(s)(P<0.01$ and $P<0.05)$. Although there was a $t \times s$ interaction on the B lymphocyte levels in the CBA matings, only $t$ was significant when tested separately against the interaction variance $(P<0.05)$. Therefore $t$ was exerting a greater effect than $s$. When $t$ and $s$ were tested against the interaction variance for the C57 matings, the $s$ effect was significant $(P<0.05)$ and $t$ was not, indicating that, in such matings, $s$ was exerting a greater effect than $t$.

The percentage of B lymphocytes in the para-aortic lymph nodes of C57 $\times$ C57. $D_{2}$ matings increased during pregnancy to about the same extent as those of C57 $\times$ C57 and C57 $\times$ CBA matings (Text-fig. 2). At 17-19 days of gestation the level in the $\mathrm{C} 57 \times \mathrm{C}^{2}$. $\mathrm{D}_{2}$ mice was significantly greater than that found in C57 virgin control mice $(P<0.01)$.

\section{Tlymphocyte levels in the brachial and para-aortic lymph nodes of $\mathrm{CBA} \times \mathrm{CBA}$ and $\mathrm{CBA} \times \mathrm{C57}$ mice}

The percentage of $\mathrm{T}$ lymphocytes in the para-aortic lymph nodes of CBA $\times$ CBA and CBA $\times$ C57 matings decreased during late pregnancy (Text-fig. 1). An analysis of variance performed 


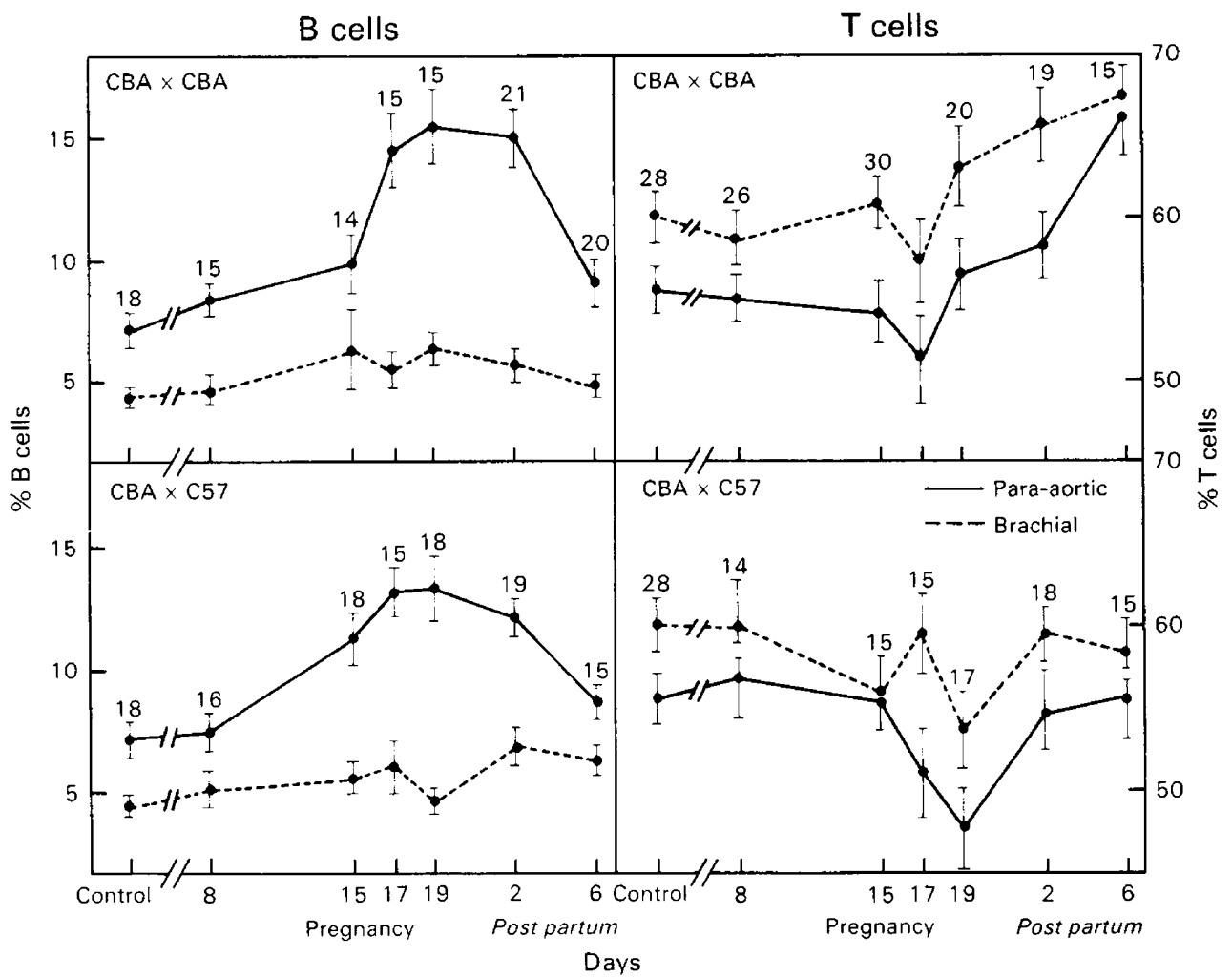

Text-fig. 1. The percentage of $T$ and $B$ lymphocytes, per 200 cells counted, in the para-aortic and brachial lymph nodes during $\mathrm{CBA} \times \mathrm{CBA}$ and $\mathrm{CBA} \times \mathrm{C} 57$ pregnancies. Values are mean \pm s.e.m. for the numbers of animals indicated.

between the percentage of $\mathrm{T}$ lymphocytes in the syngeneic and allogeneic matings showed that, although there was no significant interaction between $t$ and $s, t(P<0.01)$ and $s(P<0.05)$ were significant when tested independently. Although there was variation in the levels of $T$ cells in the brachial nodes (Text-fig. 1), an analysis of variance showed no significant effect of $t$ or $s$, and the interaction was not significant.

\section{$B$ lymphocyte percentages in the lymph nodes of $C B A \times C B A$ mice}

Effect of multiparity. There was an increase in the level of B lymphocytes in the para-aortic lymph nodes during gestation in CBA females made pregnant 4 times by CBA males and killed during the 4th pregnancy (Table 1a). The percentage of $B$ cells at 8 days and 17-19 days of pregnancy were significantly greater than in controls $(P<0.01$ and $P<0.0005$ respectively). There was no significant change in the brachial nodes.

Effect of oestrogen and progesterone. There was no significant difference between the percentage of B lymphocytes in the para-aortic lymph nodes of oil- (control) or hormone-treated mice, and the B cell levels in the hormone-treated mice differ from those of virgin controls (Table $1 \mathrm{~b}$ ). The percentages in the brachial nodes of oil- and hormone-treated mice did not differ, although the values for both groups were significantly higher than the corresponding control value $(P<0.0005$ and $P<0.01$ ).

Effect of placental pregnancy. The percentage of lymphocytes in the para-aortic lymph nodes of syngeneically mated CBA mice undergoing placental pregnancy (i.e. pregnancy without a fetus) 


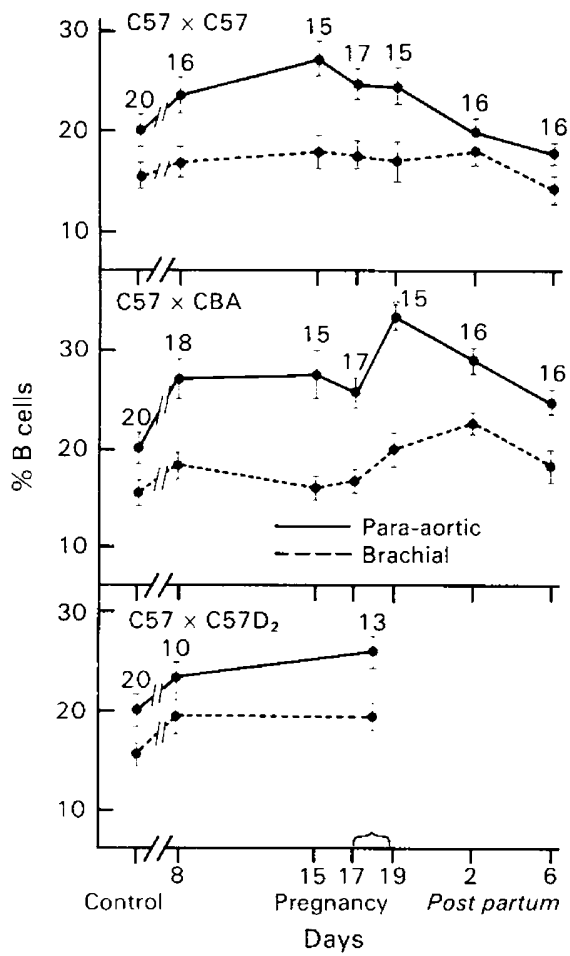

Text-fig. 2. The percentage of B lymphocytes, per 200 cells counted, in the para-aortic and brachial lymph nodes during C57 $\times$ C57, C57 $\times$ CBA and C57 $\times$ C 57.D2 pregnancies. Values are mean \pm s.e.m. for the numbers of animals indicated.

Table 1. The percentages of B lymphocytes in the lymph nodes of CBA female mice (a) during the 4th pregnancy, (b) non-pregnant, ovariectomized and treated with oil or progesterone and oestrogen for 15 days, (c) during placental pregnancy, (d) pregnant with a single male or female fetus, (e) mated with vasectomized males and (f) 8 weeks old, no treatment

\begin{tabular}{|c|c|c|c|c|}
\hline & \multirow[b]{2}{*}{ Treatment } & \multirow[b]{2}{*}{$\begin{array}{l}\text { No. of } \\
\text { mice }\end{array}$} & \multicolumn{2}{|c|}{ Mean \pm s.e.m. $\%$ of B lymphocytes } \\
\hline & & & $\begin{array}{l}\text { Para-aortic } \\
\text { lymph node }\end{array}$ & $\begin{array}{c}\text { Brachial } \\
\text { lymph node }\end{array}$ \\
\hline \multirow[t]{3}{*}{ (a) } & Age-matched controls & 13 & $7 \cdot 7 \pm 0.9$ & $6.0 \pm 0.6$ \\
\hline & Pregnant, 8 days & 15 & $9 \cdot 6 \pm 1 \cdot 0^{* *}$ & $8 \cdot 1 \pm 1 \cdot 2$ \\
\hline & Pregnant, $17-19$ days & 16 & $14.4 \pm 1 \cdot 3^{* * *}$ & $6.9 \pm 0.3$ \\
\hline \multirow[t]{2}{*}{ (b) } & Oil & 10 & $10 \cdot 1 \pm 1 \cdot 2$ & $8 \cdot 5 \pm 1 \cdot 2^{* * *}$ \\
\hline & Oestrogen + progesterone & 10 & $9.0 \pm 0.8$ & $8 \cdot 0 \pm 0.7^{* *}$ \\
\hline (c) & 17-19 days of placental pregnancy & 14 & $8.5 \pm 0.8$ & $6.8 \pm 0.7^{*}$ \\
\hline \multirow[t]{2}{*}{ (d) } & 17-19 days pregnant (male fetus) & 8 & $10.3 \pm 1.6$ & $7 \cdot 1 \pm 0.7^{*}$ \\
\hline & 17-19 days pregnant (female fetus) & 4 & $10.4 \pm 0.8$ & $4.9 \pm 1.0$ \\
\hline (e) & 17-19 days post coitum & 10 & $6.9 \pm 0.6$ & $4.8 \pm 0.6$ \\
\hline (f) & 8-week-old virgin controls & 10 & $7 \cdot 6 \pm 1 \cdot 0$ & $5.0 \pm 0.5$ \\
\hline
\end{tabular}

Means were compared with control values ${ }^{*} P<0.05 ; * * P<0.01 ;{ }^{* * *} P<0.0005$ (Student's $t$ test). 
was not significantly different from the corresponding control value (Table 1c). The level in the brachial nodes was slightly, but significantly, higher than the control level $(P<0.05)$.

Effect of a single male or female fetus. The percentages of B lymphocytes in the para-aortic and brachial lymph nodes of females carrying a male fetus were not significantly different from those in mothers carrying a female fetus (Table 1d). The B cell levels in the para-aortic lymph nodes were greater than those in controls, but not significantly so. However, the combined value for males and females was significantly different from that of the controls $(P<0.05)$. There was a slight but significant increase in the percentage of B cells in the brachial nodes compared with controls $(P<$ $0 \cdot 05$ ).

Effect of seminal plasma. The percentages of B lymphocytes in the para-aortic and brachial nodes of females mated with vasectomized males and killed 17-19 days later did not differ from that of virgin controls (Table 1e).

\section{Discussion}

These experiments were designed to investigate the effect of pregnancy on maternal levels of $T$ and B lymphocytes in lymph nodes, spleen and blood. The results for spleen and blood were inconclusive. However, during the second half of pregnancy in the mouse there was a dramatic increase in the percentage of B lymphocytes in the lymph nodes which drain the pregnant uterus; this increase is a local effect and does not occur in the brachial (underarm) nodes. In all the strain combinations examined there were slight variations in the B lymphocytes percentages in the brachial nodes but there was no obvious biological response to pregnancy in comparison to that seen in the para-aortic lymph nodes. There was also a decrease in $T$ lymphocyte percentages during late pregnancy in CBA allogeneic and syngeneic pregnancies. It is clear from the data in Text-fig. 1 that the technique used here is not sufficiently sensitive to justify further investigation with this method.

The increase in the percentage of B cells during the second half of pregnancy had not been detected previously. Baines et al. (1977b) found no change in syngeneically pregnant C57 mice examined at term using the EA-rosette forming technique for $\mathrm{Fc}$ receptors. However, it has been claimed that $\mathrm{Fc}$ receptors on $\mathrm{B}$ cells are lost when they differentiate into antibody-producing cells (Basten, Miller, Sprent \& Pye, 1972), which might explain the differences in the results. It was suggested that the allogenicity of the fetus was responsible for early changes in the B lymphocyte numbers in the para-aortic lymph nodes (Chatterjee-Hasrouni et al., 1980) but we found no changes early in pregnancy and there was no difference between syngeneic and allogeneic matings in our study for the CBA strain, although there is an indication that in the C57 $\left(\mathrm{H} 2^{\mathrm{b}}\right) \times \mathrm{CBA}\left(\mathrm{H} 2^{\mathrm{k}}\right)$ matings, where there are major and minor histocompatibility differences, there may be an increased effect. The allogeneic mating between the congenic strains $\mathrm{C} 57\left(\mathrm{H} 2^{\mathrm{b}}\right)$ and $\mathrm{C} 57 . \mathrm{D}_{2}\left(\mathrm{H} 2^{\mathrm{d}}\right)$ did not show an increase in the percentage of B cells compared with that in C57 syngeneic matings.

The antibody response to antigenic stimulation would be expected to reach a peak 3-7 days after antigenic stimulation (Wortis, Taylor \& Dresser, 1966). Implantation occurs 5 days after finding a vaginal plug in the mouse and if the reported increase was linked to this event or to seminal plasma antigens one would expect to find change in B lymphocyte levels between 3 and 12 days of pregnancy. In this study at 8 and 15 days of pregnancy there was no significant difference between the percentage of $\mathrm{B}$ cells from controls or in syngeneic or allogeneic pregnancies.

Rabbit anti-mouse IgG used in the B cell assay could bind to macrophages through the Fc receptor (Unkeless, 1977; Diamond \& Scharff, 1980). Staining with neutral red at the final stage of the indirect staining procedure showed that there were no macrophages present in the lymphocyte preparation. It was also possible that $\mathrm{T}$ lymphocytes could be detected in the B-cell assay through binding of rabbit anti-mouse IgG or goat anti-rabbit IgG to the Fc receptors (Stout \& Herzenberg, 1975 ) or to immunoglobulin-like molecules on the surface of T lymphocytes (Marchalonis, Cone \& 
Atwell, 1972). There are, however, relatively few Fc receptors on T cells (Anderson \& Grey, 1974) and those present are very labile, being shed from the cell surface very rapidly during in-vitro manipulation (Fridman \& Goldstein, 1974). Fc receptors on T cells preferentially bind aggregated immunoglobulin, the degree of binding being proportional to aggregate size and greater at 37 than $0^{\circ} \mathrm{C}$ (Anderson \& Grey, 1974). The assays used in this study were all carried out between 0 and $4^{\circ} \mathrm{C}$, so few, if any, $T$ cells would be expected to bind immunoglobulins.

In a number of instances the effect of gestation on the maternal immune response was detected only after several pregnancies (Kaliss, 1973; Bell \& Billington, 1981) or was augmented by consecutive pregnancies (Breyere \& Barrett, 1960; Baines, Millar \& Pross, 1980). The maternal graft-versus-host reactivity against total fetal transplantation antigens reaches a maximum during the 4th pregnancy (Skowron-Czendrzak, Bubak, Franczuk \& Kowalczyk, 1975). However, in the present study, primiparous and multiparous females did not differ in the percentage of $\mathbf{B}$ lymphocytes found in the para-aortic lymph nodes. Physiological doses of oestrogen and progesterone over an extended period did not affect the level of B lymphocytes in the para-aortic nodes. There was an increase in the percentage in the brachial nodes in oil-treated controls and hormone-treated animals: this increase was possibly associated with the site of injection in the dorsal neck region. The lack of an effect of allogenicity or hormones suggested that the fetoplacental unit alone might be responsible for the observed increase. Antigenic stimulation other than allogeneic differences could arise from tissue-specific placental antigens (Wiley \& Calarco, 1975; Searle, Billington, Whyte \& Loke, 1981) or the male H-Y antigen which has been shown to be present in an immunogenic form on the male conceptus (Skowron-Czendrzak, 1977). The trophoblast of the placenta is the only embryonic tissue in direct contact with the maternal circulation but during placental pregnancy, when the placenta remained viable and was delivered at term, there was no increase in the percentage of B lymphocytes in the para-aortic lymph nodes. Neither did the male fetus have any effect. The increase in the percentage of B lymphocytes did not differ in mothers carrying either a single male or a single female fetus. From these results there is also an indication that a single fetus does not cause the maximum B lymphocyte increase expected at 17-19 days of pregnancy, suggesting there may be a cumulative effect of the number of fetuses.

There is obviously a dramatic change in the B lymphocyte population in the lymph node draining the pregnant uterus at the end of pregnancy in the strain combinations used in this study. Allogenicity of the fetus, seminal plasma, implantation, multiparity, the placenta and the male fetus do not appear to be responsible for this change. The conclusion must be that the fetus itself is in some way responsible.

We thank Dr J. McKay and Professor C. Finn for helpful discussion and Mr E. Gilmartin for technical assistance. This work was supported by a grant from the Ford Foundation (No. 7800614).

\section{References}

Anderson, C.L. \& Grey, H.M. (1974) Receptors for aggregated IgG on mouse lymphocytes. J. exp. Med. 139, 1175-1188.

Ansell, J.D., McDougall, C.M., Speedy, G. \& Inchley, C.J. (1978) Changes in lymphocyte accumulation and proliferation in the lymph nodes draining the pregnant uterus. Clin. exp. Immunol. 31, 397407.

Baines, M.G., Pross, H.F. \& Millar, K.G. (1977a) Lymphocyte populations in peripheral blood during normal human pregnancy. Clin. exp. Immunol. 28, 453-457.

Baines, M.G., Pross, H.F. \& Millar, K.G. (1977b) Effects of pregnancy on the maternal lymphoid system in mice. Obstet. Gynec., N.Y. 50, 457-461.
Baines, M.G., Millar, K.G. \& Pross, H.F. (1980) Allograft enhancement during normal murine pregnancy. J. Reprod. Immunol. 2, 141-149.

Basten, A., Miller, J.F., Sprent, J. \& Pye, J. (1972) A receptor for antibody on B lymphocytes. I. Method of detection and functional significance. J. exp. Med. $135,610-626$.

Beer, A.E., Scott, J.R. \& Billingham, R.E. (1975) Histoincompatibility and maternal immunological status as determinants of fetoplacental weight and litter size in rodents. J. exp. Med. 142, 180-196.

Bell, S.C. \& Billington, W.D. (1981) Humoral immune responses in murine pregnancy. I. Anti-paternal alloantibody levels in maternal serum. J. Reprod. Immunol. 3, 3-13. 
Breyere, E.J. \& Barrett, M.K. (1960) Prolonged survival of skin homografts in parous mice. J. natn. Cancer Inst. 25, 1405-1410.

Carter, J. (1976) Expression of maternal and paternal antigens on trophoblast. Nature, Lond. 262, 292-293.

Carter, J. (1978) The expression of surface antigens on three trophoblastic tissues in the mouse. J. Reprod. Fert. 54, 433-439.

Chatterjee-Hasrouni, S., Santer, V. \& Lala, P.K. (1980) Characterization of maternal small lymphocyte subsets during allogeneic pregnancy in the mouse. Cell. Immun. 50, 290-304.

Clark, D.A., McDermott, M.R. \& Szewczuk, M.R. (1980) Impairment of host vs graft reaction in pregnant mice. II Selective suppression of cytotoxic T-cell generation correlates with soluble suppressor activity and with successful allogeneic pregnancy. Cell. Immun. 52, 106-118.

Cornfield, D.B., Jencks, J., Binder, R.A. \& Rath, C.E. (1979) $\mathrm{T}$ and B lymphocytes in pregnant women. Obstet. Gynec., N.Y. 53, 203-206.

Davies, A.J., Carter, R.L., Leuchars, E., Wallis, V. \& Koller, P.C. (1969) The morphology of immune reactions in normal, thymectomized and reconstituted mice. I. The response to sheep erythrocytes. Immunology 16, 57-69.

Diamond, B. \& Scharf, M.D. (1980) $\operatorname{IgG}_{1}$ and $\mathrm{IgG}_{2 \mathrm{~b}}$ share the $\mathrm{Fc}$ receptor on mouse macrophages. $J$. Immun. 125, 631-633.

Dickmann, Z. (1971) Egg transfer. In Methods in Mammalian Embryology, pp. 133-145. Ed. J. C. Daniel. Freeman, San Francisco.

Evans, E.P., Burtenshaw, M.D. \& Ford, C.E. (1972) Chromosomes of mouse embryos and newborn young: preparations from membranes and tail tips. Stain Technol. 47 229-234.

Fridman, W.H. \& Goldstein, P. (1974) Immunoglobulin binding factor present on and produced by thymusprocessed lymphocytes (T cells). Cell. Immunol. 11, $442-455$.

Gates, A.H. (1971) Maximising yield and development uniformity of eggs. In Methods in Mammalian Embryology, pp. 64-75. Ed. J. C. Daniel. Freeman, San Francisco.

Gottesman, S.R.S. \& Stutman, O. (1981) Comparison of cellular immune changes in the draining paraaortic lymph nodes in syngeneic and allogeneic pregnancies. In Reproductive Immunology, pp. 121-136. Ed. R. Alan. A. R. Liss, New York.

Hetherington, C.M. \& Humber, D.P. (1977) The effect of pregnancy on lymph node weight in the mouse. $J$. Immunogenet. 4, 271-276.

Hirahara, F., Gorai, I., Tanaka, K., Matzuzaki, Y., Sumiyoshi, U. \& Shiojima, Y. (1980) Cellular immunity in pregnancy: subpopulations of $\mathrm{T}$ lymphocytes bearing $\mathrm{Fc}$ receptors for $\mathrm{IgG}$ and $\operatorname{IgM}$ in pregnant women. Clin. exp. Immunol. 41, 353-357.

Kaliss, N. (1973) Immune reactions of multiparous female mice to fetal $\mathrm{H}-2$ alloantigens. In Immunology of Reproduction, pp. 495-511. Ed. K. Bratanov. Bulgarian Academy of Sciences, Sofia.
Marchalonis, J.J., Cone, R.E. \& Atwell, J.L. (1972) Isolation and partial characterization of lymphocyte surface IgG's. J. exp. Med. 135, 956-971.

Maroni, E.S. \& DeSousa, M.A.B. (1973) Lymphoid organs during pregnancy in the mouse. Clin. exp. Immunol. 13, 107-124.

Moroney, M.J. (1951) Facts from Figures, pp. 371-457. Penguin Books, Ltd, Hammondsworth.

Newton, W.H. (1945) "Pseudo-parturition" in the mouse and the relation of the placenta to post-partum oestrus. J. Physiol., Lond. 84, 196-207.

Rowley, D.A., Gowans, J.L., Atkins, R.C., Ford, W.L. \& Smith, M.E. (1972) The specific selection of recirculating lymphocytes by antigen in normal and immunized rats. J. exp. Med. 136, 499-513.

Searle, R.F., Sellens, M.H., Elson, J., Jenkinson, E.J. \& Billington, W.D. (1976) Detection of alloantigens during preimplantation development and early trophoblast differentiation in the mouse. J. exp. Med. 143, 348-359.

Searle, R.F., Billington, W.D., Whyte, A. \& Loke, Y.W. (1981) Detection of human and murine trophoblast specific antigens and as assessment of their species specificity. Placenta 2, 93-104.

Simmons, R.L. \& Russell, P.S. (1966) The histocompatibility antigens of fertilized mouse eggs and trophoblast. Ann. N.Y. Acad. Sci. 129, 35-45.

Skowron-Czendrzak, A. (1977) Immunity to male skin grafts induced in C57BL mice by interruption of syngeneic pregnancies. Folia biol. (Krakow) 25, 3-12.

Skowron-Czendrzak, A., Bubak, M., Franczuk, B. \& Kowalczyk, K. (1975) Cell-mediated immunity against paternal transplantation antigens in multiparous female mice. Folia biol. (Praha) 23, 283-291.

Snedecor, G.W. \& Cochran, W.G. (1971) Statistical Methods, 6th edn. Iowa State University Press, Ames.

Stitch, H.F. \& Hsu, T.C. (1960) Cytological identification of male and female somatic cells in the mouse. Expl Cell Res. 20, 248-249.

Stout, R.D. \& Herzenberg, L.A. (1975) The Fc receptor on thymus-derived lymphocytes. I. Detection of a subpopulation of murine $\mathrm{T}$ lymphocytes bearing the Fc receptor. J. exp. Med. 142, 611-621.

Strelkauskas, A.J., Wilson, B.S. \& Dray, S. (1975) Inversion of levels of human $\mathbf{T}$ and $\mathbf{B}$ cells in early pregnancy. Nature, Lond. 258, 331-332.

Unkeless, J.C. (1977) The presence of two Fc receptors on mouse macrophages: evidence from a variant cell line and differential trypsin sensitivity. J. exp. Med. 142, 931-945.

Wiley, L.M. \& Calarco, P.G. (1975) Effects of antiembryo sera and their localization on the cell surface during mouse preimplantation development. Devl Biol. 47, 407-418.

Wortis, H.H., Taylor, R.B. \& Dresser, D.W. (1966) Antibody production studied by means of the LHG assay. I. The splenic response of CBA mice to sheep erythrocytes. Immunology 11, 603-616. 